\title{
Pemanfaatan Jus Buah Merah (Pandanus conoideus) Sebagai Feed Additive Untuk Meningkatkan Performa Ayam Broiler Fase Starter
}

\section{Utilization of Red Fruit Juice (Pandanus conoideus) as Feed Additive to Improve The Performance of Starter Broiler Chickens}

\author{
Agus Susanto1), Agustinus G. Murwanto $^{2)}$, Sri Hartini' ${ }^{2 *}$ \\ ${ }^{1}$ Program Studi Peternakan Fakultas Peternakan Universitas Papua \\ ${ }^{2}$ Staf Pengajar Fakultas Peternakan, \\ J1. Gunung Salju Amban, Universitas Papua, Manokwari
}

\author{
Article history \\ Received: Apr 12, 2021; \\ Accepted: Jul 13, 2021 \\ * Corresponding author: \\ E-mail: \\ sri.hartini8877@gmail.com \\ DOI: \\ 10.46549/jipvet.v11i2.213
}

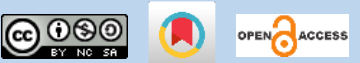

\begin{abstract}
This study aimed to determine the effect of red fruit juice (RFJ) in drinking water on feed consumption, body weight gain (BWG), feed conversion ratio and drinking water consumption of starter broiler chickens. A total of 100 broiler chickens (straight run) of 4 days old (Lohmann) were fed using commercial diets and given RFJ drinking water treatments as followed: $\mathrm{P0}=$ drinking water $1000 \mathrm{ml}+0 \mathrm{ml} \mathrm{RFJ}, \mathrm{P} 1=$ drinking water $900 \mathrm{ml}+100 \mathrm{ml} \mathrm{RFJ}, \mathrm{P} 2=$ drinking water $800 \mathrm{ml}+200 \mathrm{ml} \mathrm{RFJ}$, and $\mathrm{P} 3=$ drinking water $700 \mathrm{ml}+300 \mathrm{ml} \mathrm{RFJ}$. During the experiment, the RFJ drinking water treatments were given in a sequential pattern of 3 days $\mathrm{ON}$ and 4 days OFF. The results showed that the RFJ drinking water treatments had no effect on feed consumption $(\mathrm{P} \geq 0.05)$, but had an effect on $\mathrm{BWG}$ $(\mathrm{P}<0.05)$, feed conversion ratio $(\mathrm{P}<0.05)$, and drinking water consumption $(\mathrm{P}<0.05)$. The result of RFJ drinking water treatments on $\mathrm{BWG}$, feed conversion ratio and drinking water consumption had the same pattern, namely the best results were obtained at $200 \mathrm{ml}$ RFJ drinking water treatment and the worst at $300 \mathrm{ml}$ RFJ drinking water treatment. In conclusion, the red fruit juice at a dose of $200 \mathrm{ml}$ in 8001 of drinking water improved the performance of starter broiler chickens, whereas the red fruit juice at a dose of $300 \mathrm{ml}$ in $700 \mathrm{ml}$ of drinking water had no effect on feed consumption but had caused a decrease in the starter broiler chicken's performance.
\end{abstract}

Keywords: Body weight gain; Feed conversion ratio; Red fruit juice; Starter broiler chickens

\section{Abstrak}

Penelitian bertujuan untuk mengetahui pengaruh pemberian jus buah merah (JBM) dalam air minum terhadap konsumsi ransum, pertambahan bobot badan (PBB), konversi ransum dan konsumsi air minum ayam broiler fase starter. Penelitian menggunakan 100 ekor ayam broiler (unsexing) strain Lohmann umur 4 hari (BB awal 72,83 gram/ekor $\pm 1,03$ dan CV 0,01) yang diberi pakan ransum komersial ad libitum dan air minum perlakuan JBM sebagai berikut: $\mathrm{P0}=$ air minum 1000ml+0ml JBM, P1= air minum 900ml+100ml JBM, P2= air minum 800ml+200ml JBM, dan P3= air minum 700ml+300ml JBM. Selama penelitian, air minum perlakuan JBM diberikan mengikuti pola berurutan yaitu 3 hari ON dan 4 hari OFF. Hasil penelitian menunjukkan bahwa air minum perlakuan JBM tidak berpengaruh nyata pada konsumsi ransum $(\mathrm{P} \geq 0,05)$, tetapi berpengaruh nyata pada $\mathrm{PBB}(\mathrm{P}<0,05)$ konversi ransum $(\mathrm{P}<0,05)$, dan konsumsi air minum $(\mathrm{P}<0,05)$. Pengaruh perlakuan air minum JBM terhadap $\mathrm{PBB}$, konversi ransum dan konsumsi air minum memperlihatkan hasil dengan pola yang sama yaitu terbaik 
pada perlakuan air minum JBM $200 \mathrm{ml}$ dan terjelek pada perlakuan air minum JBM $300 \mathrm{ml}$. Kesimpulan, pemberian jus buah merah pada dosis $200 \mathrm{ml}$ dalam 8001 air minum meningkatkan performa ayam broiler fase starter lebih baik dari perlakuan kontrol, sedangkan pemberian $300 \mathrm{ml}$ jus buah merah dalam $700 \mathrm{ml}$ air tidak berpengaruh pada konsumsi ransum tetapi sudah menyebabkan penurunan performa ayam broiler fase starter lebih rendah dari perlakuan kontrol.

Kata kunci: Ayam broiler fase starter; Jus buah merah; Konversi ransum; Pertambahan bobot badan

\section{PENDAHULUAN}

Buah merah (Pandanus conoideus) sudah dikenal sejak dulu oleh masyarakat Papua, terutama oleh penduduk di wilayah pegunungan sebagai minyak makan dan tanaman obat (Wawo et al., 2016). Buah merah mengandung berbagai komponen aktif yang meliputi antara lain; $\alpha$-karoten, $\beta$-karoten, $\beta$ kriptosantin, $\alpha$-tokoferol, phosphor, asam oleat, linoleat, dan palmitat (Sarungallo et al., 2015a; 2015b), Ca, serat, protein, antikanker, penambah energi, dan vitamin B1 serta C (Ayomi, 2015). Minyak buah merah dikenal hampir di seluruh pelosok Indonesia bahkan dunia karena manfaatnya dalam meningkatkan kesehatan (Rohman and Windarsih, 2017). Kandungan asam oleat dan linoleat dalam minyak buah merah dilaporkan sekitar $69 \%$ dan 8,5\% (Rohman et al., 2012). Asam lemak tidak jenuh seperti asam linoleat sangat penting untuk ternak unggas karena termasuk dalam asam lemak essensial. Oleh karena itu tidak heran pemanfaatan buah merah sudah merambah ke ternak unggas.

Pemanfaatan buah merah sebagai feed additive dalam ransum ayam broiler telah dilakukan oleh beberapa peneliti. Ayam broiler yang diberi minyak buah merah pada dosis 0,15 cc langsung ke mulutnya memperlihatkan pertambahan bobot badan dan konversi ransum yang lebih baik dibandingkan kontrol (Untung, 2017). Ollong et al. (2012) melaporkan bahwa ayam broiler yang diberi penambahan minyak buah merah pada level 2-6\% pada ransumnya mempunyai pertambahan bobot badan yang lebih baik dibandingkan kontrol namun tidak terdapat perbedaan pada konversi ransum. Pemberian feed addtive dari tanaman obat pada ransum dilaporkan sering tidak efektif dikarenakan laju digesta pada saluran pencernaan ayam pedaging cukup cepat sedangkan zat aktif dalam tanaman obat tersebut butuh waktu dalam prosesnya untuk larut, akibatnya zat aktif daripada tanaman obat tersebut tidak sempat bekerja (Sudrajat et al., 2015). Oleh karena itu pemberian tanaman obat sebagai feed additive untuk unggas lebih baik dalam bentuk larutan ekstraknya

Fase pemeliharaan ayam broiler dibagi dalam dua fase yaitu fase starter dan fase finisher. Nutrisi yang dibutuhkan pada fase starter lebih tinggi dibandingkan fase finisher karena pertumbuhan pada fase starter relatif lebih cepat dibandingkan pada fase finisher (Hidayat et al., 2020). Megawati et al. (2020) juga menyatakan bahwa ayam broiler strain Lohmann mempunyai fase pertumbuhan tertinggi pada umur 21 hari dan melambat setelahnya. Berdasarkan kondisi tersebut, pemberian feed additive pada fase starter diharapkan dapat memacu pertumbuhan dan produktivitas ayam broiler secara maksimal. Tujuan dari penelitian ini adalah untuk mengetahui manfaat jus buah merah sebagai feed additive terhadap konsumsi ransum, pertambahan bobot badan, konversi ransum, dan konsumsi air minum ayam broiler fase starter.

\section{MATERI DAN METODE}

\section{TEMPAT DAN WAKTU PENELITIAN}

Penelitian dilakukan di Kampung Macuan, SP 5 Distrik Prafi, Kabupaten Manokwari, Provinsi Papua Barat. Penelitian memakan waktu lebih kurang 40 hari mulai dari persiapan sampai dengan pengolahan data.

\section{MATERi PENELITIAN}

Penelitian ini menggunakan seratus ekor ayam broiler strain Lohmann (unsex) umur 4 hari dengan kisaran berat badan awal adalah $72,83 \pm 1,03$ g/ekor dan koefisien ragam sebesar 0,01 , ransum komersial merek Hi-Pro- 
Vite CP 511B produksi PT. Charoen Pokphand Indonesia, serta air minum yang diberikan jus buah merah sesuai perlakuan. Adapun peralatan yang digunakan antara lain; kandang sistem litter ukuran 60 x 60 × $50 \mathrm{~cm}$ sebanyak 20 unit, timbangan digital kapasitas $5 \mathrm{~kg}$ dengan tingkat ketelitian $0,1 \mathrm{~g}$, tempat makan dan minum ukuran $1 \mathrm{~L}$, alat penyaring, blender, dan gelas ukur kapasitas 1 L. Sebagai litter digunakan serutan kayu yang dihampar setebal $\pm 5 \mathrm{~cm}$.

\section{PEMBUATAN JUS BUAH MERAH}

Jus buah merah dibuat dengan terlebih dahulu mengupas dan mencuci bersih buah merah, kemudian membelah buah merah untuk dibuang bagian tengahnya dan memotongmotong daging buah merah menjadi bentuk dadu. Daging buah merah yang sudah dipotong dadu ditambahkan air dengan perbandingan 1:1 dan diblender. Setelah diblender dilakukan penyaringan untuk diambil larutan ekstrak/ jusnya. Jus buah merah kemudian diukur sesuai dengan perlakuan.

\section{METOdE PENELITIAN}

Penelitian ini menggunakan metode eksperimen Rancangan Acak Kelompok (RAK) dengan 5 kelompok, setiap kelompok terdiri atas 4 perlakuan. Setiap satuan percobaan terdiri atas 5 ekor ayam. Pengelompokan didasarkan atas perbedaan arah sinar matahari yang masuk ke dalam kandang.

Model Linier RAK adalah: $Y_{\mathrm{ij}}=\mu+\tau_{\mathrm{i}}+\beta_{\mathrm{j}}+\varepsilon_{\mathrm{ij}}$, dimana:

$\mathrm{Y}_{\mathrm{ij}} \quad=$ hasil pengamatan (pertambahan bobot badan/ konsumsi ransum/ konversi ransum/ konsumsi air minum) pada ayam broiler fase starter dari perlakuan air minum jus buah merah ke-i $(\mathrm{i}=1$, $2,3,4)$ dalam kelompok ke-j $(\mathrm{j}=1,2,3,4,5)$

$\mu \quad=$ nilai tengah populasi

$\tau_{\mathrm{i}} \quad=$ pengaruh aditif dari perlakuan air minum jus buah merah ke-i

$\beta_{\mathrm{j}} \quad=$ pengaruh aditif dari kelompok ke-j

$\varepsilon_{\mathrm{ij}} \quad=$ pengaruh error perlakuan air minum jus buah merah ke-i pada kelompok ke-j.

\section{AIR MINUM PERLAKUAN}

Perlakuan air minum jus buah merah yang diberikan yaitu:

$\mathrm{P} 0=$ Air minum biasa sebanyak $1000 \mathrm{ml}$

$\mathrm{P} 1=$ Air minum $900 \mathrm{ml}+100 \mathrm{ml}$ Jus Buah Merah

$\mathrm{P} 2=$ Air minum $800 \mathrm{ml}+200 \mathrm{ml}$ Jus Buah Merah

P3= Air minum $700 \mathrm{ml}+300 \mathrm{ml}$ Jus Buah Merah

\section{PELAKSANAAN PENELITIAN}

Total 100 ekor ayam broiler umur 4 hari (unsexing) dialokasikan ke dalam 20 unit kandang sistem litter. Durasi penelitian adalah 21 hari. Selama penelitian, ayam diberi ransum komersial ad lbitum dan air minum perlakuan jus buah merah. Pola pemberian air minum perlakuan adalah 3 hari berturut-turut $\mathrm{ON}$ (diberikan air minum perlakuan jus buah merah) dan setelahnya 4 hari berturut-turut
OFF (diberikan air minum biasa), begitu seterusnya sampai 21 hari masa pemeliharaan. Penetapan pola pemberian air minum didasarkan pada hasil penelitian Ayomi (2015) bahwa konsumsi buah merah yang berlebihan dapat berdampak negatif pada absorpsi nutrisi dalam saluran pencernaan. Penimbangan bobot badan ayam dan ransum dilakukan pada awal penelitian, pada hari ke 7, 14 dan hari ke 21 . Pengukuran sisa air minum dan pemberian air minum dilakukan setiap hari. Penerangan diberikan selama 24 jam.

\section{VARIABEL PENGAMATAN}

Variabel yang diamati dalam penelitian ini adalah: total konsumsi ransum, pertambahan bobot badan, total konsumsi air minum pada hari ke 7, 14, dan hari ke 21. Data pertambahan bobot badan dan total konsumsi ransum digunakan untuk menghitung konversi ransum.

Rumus daripada variabel-variabel yang diamati adalah sebagai berikut: 


$$
\begin{aligned}
& \text { Konsumsi ransum (g/ekor/hari) }=\frac{\text { jumlah ransum yang diberikan }(\mathrm{g})-\text { jumlah ransum sisa }(\mathrm{g})}{\text { lama pemeliharaan (hari)xjumlah ayam(ekor) }} \\
& \text { Pertambahan Bobot Badan (gram/ekor/hari) }=\frac{\text { Berat Badan Akhir }(\mathrm{g})-\text { Berat Badan Awal }(\mathrm{g})}{\text { lama pemeliharaan }(\text { hari }) \mathrm{x} \text { jumlah ayam (ekor) }} \\
& \text { Konversi Ransum }=\frac{\text { Jumlah Konsumsi Ransum }(\mathrm{g})}{\text { Pertambahan Bobot Badan }(\mathrm{g})} \\
& \text { Konsumsi Air Minum (ml/ekor/hari) }=\frac{\text { jumlah air minum yang diberikan(ml) - jumlah air minum sisa(ml) }}{\text { lama pemeliharaan(hari) } x \text { jumlah ayam(ekor) }}
\end{aligned}
$$

\section{ANALISA DATA}

Data yang diperoleh dianalisis menggunakan SPSS (2015), apabila hasil analisis ( $\mathrm{F}$ test) signifikan, maka untuk melihat perbedaan antar perlakuan digunakan uji Tukey. Perlakuan dinyatakan berbeda nyata apabila $\mathrm{P}<0,05$.

\section{HASIL DAN PEMBAHASAN}

Respon pemberian jus buah merah dalam air minum terhadap rata-rata konsumsi ransum, pertambahan bobot badan, konversi ransum, dan konsumsi air minum ayam broiler fase starter dapat dilihat pada Tabel 1 .

\section{KONSUMSI RANSUM}

Berdasarkan Tabel 1 dapat dilihat bahwa rata-rata konsumsi ransum ayam broiler fase starter per minggu maupun selama tiga minggu tidak dipengaruhi $(\mathrm{P}>0,05)$ oleh perlakuan air minum jus buah merah.

Hasil ini mengindikasikan bahwa pemberian jus buah merah pada konsentrasi sampai dengan $30 \%$ dalam air minum masih dapat ditolerir oleh ayam broiler fase starter. Konsumsi ransum dalam penelitian ini juga masih dalam kisaran konsumsi ransum normal untuk ayam broiler strain Lohmann MB 202 yang dilaporkan sebesar 56 gram/ekor/hari (Brosur PT Japfa Comfeed Indonesia Tbk). Kandungan buah merah adalah antioksidan (dalam bentuk $\alpha$-karoten, $\beta$-karoten, $\beta$ kriptosantin, dan $\alpha$-tokoferol) dan asam lemak tidak jenuh (Sarungallo et al., 2015a; 2015b) serta mineral, vitamin dan serat (Ayomi, 2015). Pemberian jus buah merah dalam air minum diduga tidak mempengaruhi tingkat palatabilitas ransum ayam broiler, akibatnya tidak berdampak pada konsumsi ransum.

\section{PERTAMBAHAN BOBOT BADAN}

Hasil analisis statistik menunjukkan bahwa pemberian jus buah merah dalam air minum memberikan pengaruh nyata $(\mathrm{P}<0,05)$ terhadap pertambahan bobot badan (PBB) pada minggu I dan selama fase starter (minggu I III), tetapi tidak berpengaruh nyata pada minggu III $(\mathrm{P} \geq 0,05)$, sedangkan pengaruh perlakuan pada minggu II mendekati beda nyata $(\mathrm{P}=0,055) \quad$ (Tabel 1). Hasil uji Tukey menunjukkan bahwa pada minggu I rata-rata PBB perlakuan jus buah merah $100 \mathrm{ml}$ tidak berbeda nyata dengan perlakuan jus buah merah $200 \mathrm{ml}$, tetapi nyata lebih tinggi dari perlakuan kontrol dan perlakuan jus buah merah $300 \mathrm{ml}$. Urutan PBB dari yang tertinggi ke yang terendah adalah perlakuan jus buah merah 100 $\mathrm{ml}$ sebesar 17,54 g/ekor/hari, diikuti perlakuan jus buah merah $200 \mathrm{ml}$ sebesar 16,22 g/ekor/hari, kemudian perlakuan kontrol sebesar 15,58 g/ekor/hari dan perlakuan jus buah merah $300 \mathrm{ml}$ sebesar 15,44 g/ekor/hari. Selama fase starter (minggu I-III), rata-rata PBB perlakuan jus buah merah $200 \mathrm{ml}$ tidak berbeda nyata dengan perlakuan kontrol dan perlakuan jus buah merah $100 \mathrm{ml}$, tetapi nyata lebih tinggi daripada perlakuan jus buah merah $300 \mathrm{ml}$. Urutan PBB selama fase starter (minggu I-III) dari yang tertinggi ke yang terendah berturut-turut adalah perlakuan jus buah merah $200 \mathrm{ml}$ (31,95 g/ekor/hari), kemudian perlakuan jus buah merah $100 \mathrm{ml}$ (30,69 g/ekor/hari), perlakuan kontrol $(29,11$ g/ekor/hari), dan terendah perlakuan jus buah merah $300 \mathrm{ml}$ (27,94 g/ekor/hari). 
Tabel 1. Rata-rata konsumsi ransum, pertambahan bobot badan, konversi ransum, dan konsumsi air minum per minggu dan selama tiga minggu pada ayam broiler fase starter yang diberi perlakuan jus buah merah dalam air minum

\begin{tabular}{|c|c|c|c|c|c|}
\hline \multirow{2}{*}{ Minggu } & \multicolumn{4}{|c|}{ Perlakuan } & \multirow{2}{*}{ Nilai $\mathbf{P}$} \\
\hline & P0 & $\mathbf{P 1}$ & $\mathbf{P 2}$ & P3 & \\
\hline \multicolumn{6}{|c|}{ Konsumsi Ransum (gram/ekor/hari) } \\
\hline I & $27,23 \pm 1,73$ & $27,82 \pm 0,58$ & $27,15 \pm 0,77$ & $28,04 \pm 0,64$ & $0,899^{\text {ns }}$ \\
\hline II & $49,76 \pm 1,06$ & $49,98 \pm 2,08$ & $51,61 \pm 1,30$ & $47,92 \pm 1,16$ & $0,307^{\mathrm{ns}}$ \\
\hline III & $75,95 \pm 3,85$ & $81,33 \pm 1,68$ & $81,68 \pm 2,28$ & $78,06 \pm 2,51$ & $0,455^{\mathrm{ns}}$ \\
\hline I - III & $50,98 \pm 1,56$ & $53,04 \pm 0,97$ & $53,48 \pm 0,95$ & $51,34 \pm 0,73$ & $0,329^{\text {ns }}$ \\
\hline \multicolumn{6}{|c|}{ Pertambahan Bobot Badan (gram/ekor/hari) } \\
\hline I & $15,58 \pm 0,68^{a}$ & $17,54 \pm 0,28^{\mathrm{b}}$ & $16,22 \pm 0,29^{\mathrm{ab}}$ & $15,44 \pm 0,25^{\mathrm{a}}$ & $0,014^{*}$ \\
\hline II & $29,17 \pm 0,91$ & $31,60 \pm 1,62$ & $32,99 \pm 0,85$ & $29,30 \pm 0,08$ & $0,055^{\mathrm{ns}}$ \\
\hline III & $42,58 \pm 4,06$ & $42,91 \pm 3,10$ & $46,64 \pm 2,15$ & $39,09 \pm 3,15$ & $0,222^{\text {ns }}$ \\
\hline I - III & $29,11 \pm 1,35^{\mathrm{ab}}$ & $30,69 \pm 1,20^{\mathrm{ab}}$ & $31,95 \pm 0,62^{\mathrm{b}}$ & $27,94 \pm 0,73^{\mathrm{a}}$ & $0,030 *$ \\
\hline \multicolumn{6}{|c|}{ Konversi Ransum } \\
\hline I & $1,77 \pm 0,16$ & $1,59 \pm 0,43$ & $1,68 \pm 0,05$ & $1,82 \pm 0,33$ & $0,310^{\text {ns }}$ \\
\hline II & $1,71 \pm 0,30^{\mathrm{b}}$ & $1,58 \pm 0,39^{\mathrm{ab}}$ & $1,57 \pm 0,24^{\mathrm{a}}$ & $1,64 \pm 0,29^{\mathrm{ab}}$ & $0,041^{*}$ \\
\hline III & $1,82 \pm 0,10$ & $1,92 \pm 0,10$ & $1,77 \pm 0,13$ & $2,05 \pm 0,20$ & $0,144^{\mathrm{ns}}$ \\
\hline I - III & $1,76 \pm 0,05$ & $1,73 \pm 0,04$ & $1,68 \pm 0,06$ & $1,85 \pm 0,07$ & $0,058^{\mathrm{ns}}$ \\
\hline \multicolumn{6}{|c|}{ Konsumsi Air Minum (ml/ekor/hari) } \\
\hline I & $64,86 \pm 1,04^{\mathrm{ab}}$ & $66,57 \pm 1,30^{\mathrm{b}}$ & $63,08 \pm 0,40^{\mathrm{ab}}$ & $59,77 \pm 2,25^{\mathrm{a}}$ & $0,016^{*}$ \\
\hline II & $98,00 \pm 1,44^{\mathrm{b}}$ & $94,69 \pm 2,30^{\mathrm{ab}}$ & $97,77 \pm 0,65^{b}$ & $88,46 \pm 2,25^{\mathrm{a}}$ & $0,012^{*}$ \\
\hline III & $14480 \pm 5,90$ & $153,60 \pm 2,88$ & $155,03 \pm 3,76$ & $147,20 \pm 3,01$ & $0,179^{\text {ns }}$ \\
\hline I - III & $102,55 \pm 2,11^{\mathrm{ab}}$ & $104,95 \pm 0,97^{\mathrm{b}}$ & $105,30 \pm 1,36^{\mathrm{b}}$ & $98,47 \pm 1,20^{\mathrm{a}}$ & $0,018^{*}$ \\
\hline
\end{tabular}

Keterangan: P0 = Kontrol (air minum biasa), $\mathrm{P} 1=$ air minum $900 \mathrm{ml}+$ jus buah merah $100 \mathrm{ml}, \mathrm{P} 2=$ air minum $800 \mathrm{ml}$ $+200 \mathrm{ml}$ jus buah merah, P3 = air minum $700 \mathrm{ml}+300 \mathrm{ml}$ jus buah merah. Huruf yang berbeda pada baris yang sama menunjukkan beda nyata. *beda nyata $(\mathrm{P}<0,05)$, ns $=$ non significant (tidak berbeda nyata, $\mathrm{P}>0,05)$. SEM $=$ standard error of means.

Dari hasil di atas dapat dilihat bahwa rataan PBB selama fase starter untuk perlakuan jus buah merah $200 \mathrm{ml}$ lebih tinggi dibandingkan perlakuan jus buah merah 300 $\mathrm{ml}$, namun hanya secara numerik lebih tinggi dari perlakuan kontrol dan perlakuan jus buah merah $100 \mathrm{ml}$. Pola yang sama terlihat pada minggu ke II meskipun hasil statistik menunjukkan non signifikan. Hasil ini mengimplikasikan bahwa pemberian jus buah merah sebanyak $200 \mathrm{ml}$ dalam air minum merupakan dosis optimal untuk pertambahan bobot badan.
Pertambahan bobot badan dipengaruhi oleh konsumsi ransum dan konversi ransum. Konsumsi ransum yang tinggi atau konversi ransum yang baik akan meningkatkan PBB. Dalam penelitian ini konsumsi ransum tidak berbeda nyata, jadi meningkatnya PBB kemungkinan adalah karena konversi ransum yang lebih baik. Hasil analisis ragam pada konversi ransum mendukung pernyataan ini. Hasil penelitian pada PBB ini sejalan dengan hasil penelitian Yuanita (2009) dan Ollong et al. (2012), dimana masing-masing mendapatkan bahwa pemberian ampas dan minyak buah merah dapat meningkatkan bobot 
badan ayam broiler. Meskipun bentuk fisik buah merah pada penelitian sebelumnya tidak sama, namun kandungan buah merah tetaplah sama sehingga diduga efek fisiologis yang terjadi dalam sistem pencernaan tidak berbeda.

\section{KONVERSI RANSUM}

Pada Tabel 1 nampak bahwa penambahan jus buah merah dalam air minum berpengaruh nyata terhadap konversi ransum pada minggu II $(\mathrm{P}<0,05)$, tetapi tidak berpengaruh nyata terhadap konversi ransum pada minggu I dan minggu III $(\mathrm{P} \geq 0,05)$, sedangkan pengaruh perlakuan selama fase starter (minggu I-III) mendekati beda nyata $(\mathrm{P}=0,058)$. Hasil uji lanjut menunjukkan bahwa pada minggu II, perlakuan jus buah merah $200 \mathrm{ml}$ mempunyai nilai rataan konversi ransum $(1,57)$ lebih baik dibandingkan perlakuan kontrol $(1,71)$, namun tidak berbeda dengan perlakuan lainnya. Rataan nilai konversi ransum untuk perlakuan jus buah merah $200 \mathrm{ml}$ lebih baik daripada perlakuan jus buah merah $100 \mathrm{ml}(1,58)$ dan $300 \mathrm{ml}(1,64)$. Selama fase starter (minggu IIII), hasil statistik pada konversi ransum hanya mendekati beda nyata. Apabila dilihat dari hasil yang didapatkan, ada tendensi bahwa perlakuan jus buah merah $200 \mathrm{ml}$ mempunyai nilai rataan konversi ransum $(1,68)$ lebih baik dibandingkan perlakuan lainnya. Hal ini menjawab hasil yang didapat pada PBB, dimana perlakuan jus buah merah $200 \mathrm{ml}$ mempunyai PBB tertinggi (31,95 g/ekor/hari) dan perlakuan jus buah merah $300 \mathrm{ml}$ mempunyai PBB terendah (27,94 g/ekor/hari). Menurut Yuanita (2009), pemberian ampas buah merah dapat menyebabkan permukaan villi usus yang lebih luas sehingga meningkatkan pencernaan dan penyerapan nutrisi. Selanjutnya Ollong et al. (2017) melaporkan bahwa penambahan ampas buah merah dalam ransum meningkatkan panjang saluran pencernaan yang mengimplikasikan meningkatnya permukaan usus, akibatnya absorpsi nutrisi akan meningkat pula. Berdasarkan hal ini dapat dikatakan bahwa pemberian jus buah merah pada dosis $200 \mathrm{ml}$ merupakan dosis optimal dalam mempengaruhi fungsi fisiologis pencernaan.

\section{KONSUMSI AIR MINUM}

Hasil analisis statistik menunjukkan bahwa pengaruh penambahan jus buah merah dalam air minum berpengaruh nyata $(\mathrm{P}<0.05)$ terhadap konsumsi air minum pada minggu I, minggu II dan minggu I-III, namun tidak berpengaruh nyata $(\mathrm{P}>0.05)$ pada minggu III (Tabel 1). Hasil uji lanjut menunjukkan bahwa pada minggu I, II dan minggu I-III, rata-rata konsumsi air minum pada perlakuan kontrol, perlakuan jus buah merah 100 dan $200 \mathrm{ml}$ tidak berbeda nyata $(\mathrm{P}>0.05)$, tetapi nyata lebih tinggi dari perlakuan jus buah merah $300 \mathrm{ml}$. Selama fase starter, konsumsi air minum tertinggi didapatkan pada perlakuan jus buah merah $200 \mathrm{ml}$ sebanyak 105,30 ml/ekor/hari, diikuti perlakuan jus buah merah $100 \mathrm{ml}$ sebanyak 104,95 ml/ekor/hari, kemudian perlakuan kontrol sebanyak 102,55 $\mathrm{ml} /$ ekor/hari, dan terendah pada perlakuan jus buah merah $300 \mathrm{ml}$ sebanyak 98,47 $\mathrm{ml} / \mathrm{ekor} / \mathrm{hari}$.

Menurut Prayitno dan Sugiharto (2015), ayam mampu membedakan rasa dan aroma. Rendahnya konsumsi air minum pada perlakuan jus buah merah $300 \mathrm{ml}$ diduga ada 2 kemungkinan yaitu; 1) karena palatabilitas air minum sudah berkurang sehingga menyebabkan konsumsi air minum menurun atau 2) aroma dari perlakuan jus buah merah $300 \mathrm{ml}$ kurang disukai oleh ayam sehingga mempengaruhi konsumsi air minum. Konsumsi air pada ayam broiler memiliki standar tertentu dan ayam broiler tidak akan mengkonsumsi air secara berlebihan bila tidak dalam keadaan stress misal karena suhu yang terlalu tinggi (Khumaini et al., 2012). Menurut Singleton (2004), konsumsi air minum ayam broiler dalam temperatur normal sekitar 1,8-2 kali dari jumlah konsumsi ransum. Hasil penelitian mendukung pernyataan ini.

\section{KESIMPULAN}

Berdasarkan hasil penelitian dapat disimpulkan bahwa pemberian jus buah merah pada dosis $200 \mathrm{ml}$ dalam $800 \mathrm{ml}$ air minum dapat meningkatkan pertambahan bobot badan, konversi ransum dan konsumsi air minum ayam broiler fase starter lebih baik dibandingkan dengan perlakuan kontrol, dengan kata lain pemberian dosis $200 \mathrm{ml}$ jus buah merah dalam $800 \mathrm{ml}$ air minum dapat meningkatkan performa ayam broiler fase starter. Pemberian jus buah merah pada dosis $300 \mathrm{ml}$ dalam $700 \mathrm{ml}$ 
air minum tidak berpengaruh pada konsumsi ransum tetapi sudah menyebabkan PBB, konversi ransum dan konsumsi air minum menurun lebih rendah dari perlakuan kontrol.

\section{DAFTAR PUSTAKA}

Ayomi AFM. 2015. Buah Merah (Pandanus conoideus) terhadap penyerapan zat besi $(\mathrm{Fe})$ dalam duodenum. Jurnal Kesehatan dan Agromedicine 2 (2) : 90-93.

Hidayat DF, Widodo A, Diyantoro and Yuliani MGA. 2020. The effect of providing fermented milk on the performance of Gallus domesticus. Journal of Applied Veterinary Science and Technology 1: 43047.

DOI: 10.20473/javest.V1.I2.2020.43-47

Khumaini A, Mudawaroch RE dan Hanung DA. 2012. Pengaruh penambahan sari kunyit (Curcuma domestica Val) dalam air minum terhadap konsumsi pakan dan konsumsi air minum ayam broiler. Surya Agritama 1(2): 85-93.

Megawati NI, Dhamayanti Y, Purnama MTE, Soeharsono, Yudhana A dan Yunita MN. 2020. Pola pertumbuhan ayam broiler strain lohmann berdasarkan osteometri tulang sayap. Jurnal Medik Veteriner 3 (2): 216-223.

DOI:

10.20473/jmv.vol3.iss2.2020.216-223

Ollong AR, Wihandoyo dan Erwanto Y. 2012. Penampilan produksi ayam broiler yang diberi pakan mengandung minyak buah merah (Pandanus conoideus Lam.) pada aras yang berbeda. Buletin Peternakan 36 (1): 14-18.

Ollong AR, Tethool AN dan Arizona R. 2017. Pengaruh berbagai taraf ampas buah merah (Pandanus Conoideus Lam) dalam ransum komersial terhadap persentase panjang dan bobot organ pencernaan itik lokal jantan. Prosiding Seminar Nasional Peternakan 3, Makassar 18 September 2017. Hal 173180.

Prayitno DS dan Sugiharto. 2015. Kesejahteraan dan Metode Penelitian Tingkah Laku Unggas. Semarang: Badan Penerbit Universitas Diponegoro.

Rohman A, Sugeng R and Che Man YB. 2012. Characterization of red fruit (Pandanus conoideus Lam) oil. International Food Research Journal 19 (2): 563-567.

Rohman A and Windarsih A. 2017. Characterization, biological activities, and authentication of red fruit (Pandanus conoideus Lam) oil. Food Research 2 (2): 134-138. DOI: 10.26656/fr.2017.2(2).152

Sarungallo ZL, Hariyadi P, Andarwulan N, Purnomo EH and Wada M. 2015a. Analysis of $\alpha$-cryptoxanthin, $\beta$ cryptoxanthin, $\alpha$-carotene, and $\beta$-carotene of pandanus conoideus oil by highperformance liquid chromatography (HPLC). Procedia Food Science 3: 231243. DOI: $10.1016 /$ j.profoo.2015.01.026

Sarungallo ZL, Hariyadi P, Andarwulan N and Purnomo E H. 2015b. Characterization of chemical properties, lipid profile, total phenol and tocopherol content of oils extracted from nine clones of red fruit (Pandanus Conoideus). Kasetsart Journal (Natural Science) 49: 237-250.

Singleton R. 2004. Hot weather broiler and breeder management. Asian Poultry Magazine September 2002: 26-29.

SPSS. 2015. IBM SPSS Statistics 23. IBM Corporation. New York.

Sudrajat D, Kardaya D, Malik B dan Abas. 2015. Pengaruh larutan daun sirih dalam air minum sebagai pengganti antibiotik terhadap retensi nitrogen dan energi metabolis ransum. Jurnal Peternakan Nusantara 1 (1): 33-38.

Untung. 2017. Performans ayam pedaging setelah pemberian berbagai dosis minyak buah merah (Pandanus conoideus Lam) melalui tetes mulut. Jurnal Fapertanak II (1): 20-30.

Wawo AH, Agusta A dan Setyowati N. 2016. Studi cara perbanyakan buah merah (pandanus conoideus) dan upaya konservasinya di Lembah Balim, Kabupaten Jayawijaya Papua. Prosiding Seminar Nasional Biologi (SAMABIO), 31 Mei 2016, Bandung, Indonesia.

Yuanita I. 2009. Pemanfaatan Ampas Buah Merah (Pandanus Conoideus) sebagai Pakan Tambahan Ayam Pedaging: Penampilan Produksi dan Status Kesehatan Ayam. Tesis. Sekolah Pascasarjana, Institut Pertanian Bogor, Bogor. 